\section{About an Ethical Interpretation of the Law. Resolution of the Civil Action during the Criminal Trial}

Florin Octavian BARBU ${ }^{1}$, Claudiu Gabriel NEACŞU ${ }^{2}$

${ }^{1} \mathrm{PhD}$ Student, "Academician Andrei Radulescu" Institute of Legal Research, Romanian Academy, Bucharest, Romania, florin octavian2000@yahoo.com

${ }^{2}$ Faculty of Law and Administrative Sciences, Valahia University of Targoviste, Romania, claudiugabriel0@gmail.com

\begin{abstract}
From the provisions of art. 25 para. 1 and art. 397 para. 1 of the Criminal Procedure Code, as in the previous regulation, it results that the legislator took into account an element not only of civil justice, but also of social ethics, when it was established that the criminal court also rules, through the same decision, on the action civil. Basically, the two provisions stated above express the same idea, although this repetition was not absolutely necessary. From the current regulation of solving the civil action during the criminal trial, we notice that the legislator has maintained a series of general principles such as: cases of ex officio settlement of the civil action, dependence of the civil action on the way the criminal action is settled, the disjunction of the civil action from the criminal proceedings, the failure to resolve the civil action as a distinct procedure from that of admitting or rejecting the civil action, resolving the civil action only by the court, and the interdiction to resolve it during the criminal investigation, which, however, were adapted to a new legislative vision.
\end{abstract}

Keywords: disjunction, civil action, resolution, criminal action, agreement.

How to cite: Barbu, F.O., \& Neacşu, C.G. (2020). About an Ethical Interpretation of the Law. Resolution of the Civil Action during the Criminal Trial. Journal for Ethics in Social Studies, 4(1), 31-43.

https://doi.org/10.18662/jess/4.1/26 


\section{Introduction}

When we refer to the current legislative vision, we refer, for example, not only to the hypothesis of the plea bargain, regulated by art. 478 and the following of the Criminal Procedure Code (with civil implications, in view of the provisions of art. 486 of the Criminal Procedure Code), but also to the fact that art. 16 of the Criminal Procedure Code proceeds to a redisposition of the cases that prevent the initiation and exercise of the criminal action (Barbu, 2016, p. 34). Article 16 para. 1 of the current Criminal Procedure Code provides that: "the criminal action cannot be initiated, and when it has been initiated, it cannot be exercised if: a) the crime does not exist; b) the crime is not provided by the criminal law or was not committed with the guilt provided by law; $\mathrm{c}$ ) there is no evidence that a person committed the crime; d) there is a justifying or non-imputable cause; e) the prior complaint, authorization or notification of the competent body or another condition provided by law, necessary for the initiation of the criminal proceeding, is missing; f) the amnesty or the prescription intervened, the death of the suspect or of the defendant who is a natural person or the deregistration of the suspect or the defendant who is a legal person was ordered; g) the preliminary complaint has been withdrawn, in case of crimes for which its withdrawal puts an end to the criminal liability, the reconciliation has taken place or a mediation agreement has been concluded under the law; h) there is a cause of impunity provided by law; i) there is res judicata authority; j) there has been a transfer of proceedings with another state, according to the law".

As novel elements in the current criminal procedure regulation (compared to the provisions of the previous Criminal Procedure Code) we mention: the repeal of the case provided by art. 10 letter b1 of the previous Criminal Procedure Code (Romanian Parliament, 1968), as a consequence of the removal of social danger as an essential element of the crime, the express stipulation in art. 16 letter $\mathrm{d}$ of the Criminal Procedure Code of the justifying causes or general non-imputability causes, corresponding to the changes that are found in the new Criminal Code in art. 18-22 (self-defense, state of necessity, exercise of a right or fulfillment of an obligation, consent of the victim] and art. 23-31 (physical coercion, moral coercion, imputable excess, perpetrator's minority, irresponsibility, intoxication, error, fortuitous event), or special non-imputability causes, as are, for example, those provided by art. 272 para. 2; merging into one single provision the two cases provided in art.10 letters b and d of the former Criminal Procedure Code in art. 16 letter 
$\mathrm{b}$ of the new Criminal Procedure Code; regulation of art. 16 letter $j$ as a new case of obstruction to exercise criminal proceedings.

\section{Possible rulings during the criminal trial regarding the civil action}

\subsection{The solution to declare the civil action as admissible}

Irrespective of the solution pronounced in the criminal action, in the cases that will be reviewed below, the court may proceed to admit the civil action, in whole or in part, the last solution being equivalent to a partial rejection of the claims of the civil party.

The admission, in whole or in part, of the civil action takes place in the following situations, conditioned in all cases by the fact that damage was caused to the civil party, so effectively by cumulatively meeting of the conditions of tortious civil liability:

- when the defendant is convicted;

- when the defendant is acquitted based on art. 16 para. 1 letter b second thesis of the Criminal Procedure Code (the deed was not committed with guilt as provided by law), art. 16 para. 1 letter $\mathrm{d}$ of the Criminal Procedure Code (there is a justifiable or non-imputable cause);

- when charges are dropped, based on art. 16 para. $\mathrm{h}$ (there is a general cause of impunity provided by law, such as the one provided in art. 34 of the Penal Code, or a special impunity cause, such as those provided in art. 273 para. 3 and art. 290 para. 2 and 3 of the Penal Code).

In connection with the admission of the civil action, we consider it necessary to make the following observations. Thus, according to art. 397 para. 6 of the Criminal Procedure Code, in case the civil action is admitted, the court orders that the payment of the civil damage be deducted from the bail (if this measure has been taken), under the conditions of art. 217 of the Criminal Procedure Code.

Thus, the provisions of art. 217 par. 7 of the Criminal Procedure Code state that the damages to be deducted from the amount of the bail will be paid in the following order of preference expressly stipulated by law: the monetary compensations granted for repairing the damages caused by the crime, the court expenses, and fines. Therefore, the payment of civil damages is a priority according to the order expressly stated by these legal provisions.

Basically, we are speaking about the case when, during the criminal investigation, the preliminary chamber procedure or the trial, the preventive measure of judicial control on bail was taken against the defendant or another preventive measure was replaced by bail (Barbu, 2019). 
We note, therefore, that the bail is meant, first of all, to repair the damage caused by the crime (as well as to cover other sums of money, as mentioned in art. 217 para. 7 of the Criminal Procedure Code) and, only subsequently, the restitution of the bail gets to be returned (art. 217 para. 6 of the Criminal Procedure Code) or confiscated when the judgement is issued, in case the measure of judicial control on bail has been replaced with the measure of house arrest or with that of pre-trial detention (art. 277 para. 6 of the Criminal Procedure Code).

We also note that the bail can be used to pay for damages only if the case is trialed, because, according to art. 217 para. 8 of the Criminal Procedure Code, in case of non-litigation, the prosecutor also orders the return of the bail. This appears natural, because the resolution of the civil action really falls within the prerogative of the court (contrary to the isolated and criticizable disposition from art. 318 par. 3 letters a and b of the Criminal Procedure Code, which we will comment towards the end of the section dedicated to solving the civil action during the criminal trial). We show that, in our opinion, in the hypothesis that the case is solved during the criminal trial phase through a solution of dropping or waiver of the charges (and the judgement remains unappealed under the conditions of art. 340 and the following of the Criminal Procedure Code), the injured party should only have the possibility to obtain the indemnification of the material or moral damage by way of a civil lawsuit, and this is why, de lege ferenda, we propose the repeal of the provisions of art. 318 para. 3 letters a and $b$ of the Criminal Procedure Code regarding the ordinance to drop charges, with the consequence of the correlative and partial modification of art. 318 para. 4 and para. 5 of the Criminal Procedure Code.

In connection with these topical provisions of art. 217 of the Criminal Procedure Code, which represent a novel element of the current regulation, we consider that, de lege ferenda:

- on the one hand, this text of law should be rearranged, out of the need for accuracy in expressing the legal order, in order to express, regarding the legal institution of bail, first the rule, then the exceptions. Thus, para. 1 4 should remain in the current order, para. 9 should become par. 5, para. 7 should become par. 6 , and it should also be adapted in the sense that the court, by judgement, should be able to order the deduction from the bail of certain sums of money, in the following order: the monetary compensations granted for the reparation of the damage caused by the crime, the judicial expenses, the payment of the fine, para. 5 and 6 should become para. 7 and 8 , and para. 8 should become para. 9; 
- on the other hand, from the point of view of the civil action to be solved during the criminal trial and of the possibility that the civil and the criminal action are not solved at once, we consider that it would be beneficial to add a paragraph (or even a mention in the current art. 217 para. 6 of the Criminal Procedure Code) to expressly include the possibility to seize the bail at the disposal of the court, until the moment of the final settlement and of the civil action, if its resolution should be separated from the criminal action, for reasons of an expeditious trial and priority to judge the criminal action.

\subsection{The solution to dismiss the civil action}

The dismissal of the civil action can occur in the following circumstances:

- when the defendant is acquitted based on art. 16 letter a of the Criminal Procedure Code (the imputed crime does not exist), or art. 16 letter c of the Criminal Procedure Code (there is no evidence that a person committed the crime), as those cases were previously treated by the legal doctrine (Neagu, 2020, p. 257) (under the provisions of art. 10 letters a and c of the previous Criminal Procedure Code) as separate grounds for dismissal of the civil action, because in such cases civil damages were not granted, which, in reality, is also a decision to dismiss the civil action;

- when the civil action has no legal basis, i.e. when the criminal court does not establish that the elements of tortious civil liability are cumulatively met (for example, in case of lack of fault in causing the damage).

We also show that the old theoretical discussions regarding the compensations for judicial errors from the old criminal procedural regulation remain pending (Neagu, 2020, p. 257), because the current Criminal Procedure Code did not bring consistent improvements in this aspect through the provisions of art. 538-542. We therefore maintain the observations made above. In addition, we add the fact that the principle and consequences of the principle of avoiding enrichment without just cause, not previously regulated by the substantive civil law, but recognized jurisprudentially, were expressly provided by art. 1345 of the Civil Code (which stipulates that: "he who, imputably, became rich without just cause to the detriment of another is obliged to restitution, to the extent of the patrimonial loss suffered by the other person, but is not liable beyond the limit of their enrichment") and, at the same time, were maintained by art. 1344 of the Civil Code (" restitution of undue payment is made according to the provisions of art. 1635-1649"), and the consequences of undue payment. 
Regarding the cases when entering the trial as a civil party (Barbu, 2017 ) is tardy or does not meet the requirements provided by art. 20 para. 2 of the Criminal Procedure Code, we reiterate that, according to art. 20 para. 4 of the Criminal Procedure Code, the civil action cannot be solved during the criminal trial, and the civil party can only file a complaint before the civil court. In this case, there is no actual resolution of the civil action, as a sanction. As this is an invalid civil action, the court should expressly state this circumstance and, moreover, should do so not only at the end of the criminal trial, but by a formal procedural decision (this is why I proposed the amendment of this text of law) taken at the time when the civil action is found to be flawed (for example, to avoid unnecessary evidence). Therefore, it is not about a real dismissal of the civil action, but about the need that the court, in conclusion or in the operative part of the decision, make an express reference to the invalidity of filing the civil action and to the sanction provided by art. 20 para. 4 of the Criminal Procedure Code. Thus, the injured persons could be able to file an action before the civil court, sheltered from the possible incidence of the res judicata limitation.

In our opinion, in a case brought before the appellate court under the new regulation, which is immediately applicable, filing a civil lawsuit without submitting the documents proving the damage and without requesting that some kind of evidence should be administered should lead to the express incidence of art. 20 para. 4 of the Criminal Procedure Code, and not to the dismissal of the civil action as unproven. Otherwise, the provisions of art. 20 para. 4 of the Civil Procedure Code in a possible civil trial would give rise to unnecessary discussions related to the incidence of res judicata.

\subsection{Failure to decide upon the civil action}

The civil action is left unresolved in the cases regulated by art. 25 para. 5 and 6 of the Criminal Procedure Code and art. 486 para. 2 of the Criminal Procedure Code. These situations are as follows:

- when the court orders the acquittal of the defendant based on art. 16 para. 1 letter $b$ thesis I of the Criminal Procedure Code (the deed is not provided by the criminal law) - art. 25 para. (5) of the Criminal Procedure Code;

- when the court decides the forfeit of the criminal trial based on art. 16 para. 1 letter e (there is no prior complaint, authorization or notification or other condition provided by law, necessary for initiating the criminal action), letter $f$ (amnesty, prescription, death of the defendant who is a natural person or the dissolution of the legal person), letter $g$ (the 
preliminary complaint was withdrawn in case of crimes for which its withdrawal precludes criminal liability, the reconciliation intervened or a mediation agreement was concluded under the law) of the Criminal Procedure Code - art. 25 alin. (5) of the Criminal Procedure Code.

We welcome the possibility brought on by the Decision of the Constitutional Court no. 586 of September 13th, 2016 that in case of prescription of the criminal liability, the civil action can be further judged during the criminal trial.

Regarding the situation when the non-settlement of the civil action occurs in relation to the reconciliation of the parties, we notice that this text is in contradiction with the provisions of art. 159 para. 2 of the Penal Code, that expressly states about the forfeit of the civil action, a fact that was, judiciously, considered apt to generate a non-unitary practice ("Aspects of Non-Unitary Practice", 2014). Starting from this discrepancy, the opinions expressed after a meeting from November 27-28th, 2014 of between representatives of the Superior Council of Magistracy with the presidents of the criminal sections of the High Court of Cassation and Justice and the Courts of Appeal is interesting. Thus, it was decided that, with regard to civil action brought by persons other than the victim of the crime (for example, hospital units in case of road accidents), there should be an express mention in the operative part of the judgement regarding the unresolved civil action (based on the Criminal Procedure Code), while the civil action exercised by the injured person who reconciles with the defendant will be forfeit based on the provisions of the Criminal Code. It is obvious that, by law, it is necessary to reconcile these provisions, regardless of which solution is embraced;

- when there was a transfer of proceedings with another state under the law, according to art. 16 para. 1 letter j of the Criminal Procedure Code art. 25 para. 5 of the Criminal Procedure Code;

- when, according to art. 25 para. 5 of the Criminal Procedure Code, the court admits the plea bargain and no transaction or mediation agreement has been concluded between the parties regarding the civil action, according to art. 486 para. 2 of the Criminal Procedure Code, while observing that it is expressly provided that the decision to enforce the plea bargain does not have the authority of res judicata on the extent of the damage before the civil court. However, by reference to the provisions of art. 28 para. 1 thesis I of the Criminal Procedure Code, the decision of the criminal court by which the plea bargain is admitted has the authority of res judicata regarding the existence of the crime and of the person who committed it. Moreover, this court decision res judicata civil matters also in terms of the existence of 
damage and guilt of the perpetrator, which is deduced from the per a contrario interpretation of the provisions of art. 28 para. 1 thesis II of the Criminal Procedure Code (not a case of acquittal or termination of criminal proceedings). Therefore, from the point of view of civil claims before the civil court, practically, the necessary evidence will be administered in order to quantify the damage, a matter left unresolved during the criminal trial, in the absence of an agreement between the parties and the impossibility to disjoin the civil lawsuit from the criminal one - art. 486 para. 2 of the Criminal Procedure Code.

We appreciate that the adoption of this solution, provided by art. 486 para. 2 of the Criminal Procedure Code, is unfair from the point of view of protecting the rights and interests of the victims, who become obliged, in practice, to make new efforts and diligence to bring a lawsuit before the civil court, thus even postponing the possibility of their compensation. Since the plea bargain is within the jurisdiction of the court (art. 485 of the Criminal Procedure Code), and in case of admission of this agreement we are, practically, in the hypothesis of a court decision, we believe that, de lege ferenda, given that the Romanian legislator continued to opt for the system of filing a civil lawsuit during the criminal proceedings, it would be beneficial to have the possibility of exercising the civil action in criminal proceedings (if it has been not already been filed during the criminal trial and the administration of evidence is necessary). If this is procedure is chosen, the civil action should be disjointed from the criminal action, but it should be also solved by the criminal court. In the sense of such an amendment of art. 486 para. 2 of the Criminal Procedure Code, consisting in the disjunction of the civil action, we believe that the same reasons that led to providing a similar procedure are applicable, the plea bargain - art. 374 para. 5 in conjunction with art. 26 of the Penal Code. It is curious how the legislator intended some protection of the victim's interests in the case of the prosecutor's solution to drop the charges (art. 318 of the Criminal Procedure Code), but did not do the same in the special procedure in question. Therefore, even if the plea bargain is meant to ensure an expeditious trial, we believe that the victim should still be allowed to choose whether or not to capitalize on their claims in criminal proceedings, and not to be restricted to exercise this right of option because of the way the criminal matter was resolved, a resolution that they have no power to control. Until such an amendment of the law, all that remains is for the courts to leave the civil action unresolved, as it is currently the case (Cluj-Napoca Court, criminal sentence no. 326 of March 28, 2014); 
- when, according to art. 25 para. 6 of the Criminal Procedure Code, the heirs or, as the case may be, the successors in rights or liquidators do not express their option to exercise the civil action or, as the case may be, the civil party does not indicate the liquidators of the civilly responsible party within the term provided in art. 24 para. 1 and 2 . We are speaking about the maximum two months term that starts when taking note of the respective circumstance, but, for accuracy in expression, we consider that, de lege ferenda, we propose the following format of art. 25 para. 6 of the Criminal Procedure Code: "the court leaves the civil action unresolved, even if the heirs or, as the case may be, the successors in rights or liquidators of the civil party do not express their option to continue exercising the civil action within the term provided in art. 24 para. 1 or, as the case may be, the civil party or the defendant do not indicate the heirs, successors in rights or liquidators of the civilly responsible party within the term provided in art. 24 para. 2";

- when, according to art. 25 para. 5 of the Criminal Procedure Code, criminal charges are dropped as a result of the withdrawal of the preliminary complaint. In this sense, the initial provisions of art. 25 para. 5 were modified by art. II point 2 of the Emergency Ordinance no. 18/2016. Thus, the withdrawal of the preliminary complaint has an impact exclusively on the criminal proceedings, but not on the civil claims, that can be capitalized through a purely civil action.

It can be observed that, in the current regulation, the cases when the civil action is not solved during the criminal trial and the only other procedure left is to appeal to civil jurisdiction are much more numerous than in the previous regulation. Thus, the case currently regulated in art. 16 para. 1 letter $\mathrm{f}$ did not constitute an impediment for solving the civil action in the criminal trial - see the case regulated by art. 10 letter $g$ of the previous Criminal Procedure Code. That is why we appreciate that, unfortunately, the current Code represents a setback in terms of the interests of victims, and we are witnessing an increasingly obvious, even if not expressly recognized, dismissal of the mixed system that offers the possibility of joining the two actions within criminal trial.

It is also important that the failure to resolve the civil action during the criminal trial does not represent a dismissal of the civil action, so that the solution to file a civil lawsuit in order to recover the damage remains open, and the prescription of the exercise of a civil action before the civil court must be appreciated in accordance with the date when the criminal judgement was issued. In this respect, the solutions in the jurisprudence prior to the entry into force of the current Criminal Procedure Code are still 
valid today (HCCJ, 2010). In a decision of this sort, the High Court of Cassation and Justice states that: "As in the case of penal judgement no. 32 of January 17, 2008 of the Court of Constanța, penal section, the civil action filed by the plaintiff was not resolved, it cannot be held - as the appellate court wrongly did - that this amounts to dismissing the plaintiff's civil application, so that (. ..), the prescription of the appellant's right of action against the respondent defendant starts to run again from the date of pronouncing the mentioned sentence (...), date in relation to which the introduction of the action (...) is made within the limitation period provided by the prescription term (.. .), the solutions retained by the courts of appeal being therefore illegal and unfounded ". As a result, it is correct to state that from the point of view of the immediate application of the provisions of the current Criminal Procedure Code (although these provisions are not at the same time ethical or fair, given the prolongation of judicial proceedings for the recovery of the damage, through a new civil lawsuit, in the event that the recovery of the damage is still desired), the civil action of all the civil parties was left unresolved as a result of the prescription of criminal liability (ClujNapoca Court, criminal sentence no. 505 of May 7th, 2014).

At the same time, as a guarantee that the damage will be repaired, precautionary measures can be taken during the criminal trial, regardless of the procedural phase, measures that are even mandatory in the case of persons protected by art. 19 para. 3 of the Criminal Procedure Code. As a way of protecting the victims constituted as civil parties whose action was left unresolved during the criminal trial, according to art. 397 para. 5 of the Criminal Procedure Code, their status is maintained, provided that the injured person files a lawsuit before a civil court within a maximum of 30 days from the conclusion of the criminal trial. This safeguarding of the victims' interests is provided only for the solutions of non-settlement of the civil action taken based on art. 25 para. 5 of the Criminal Procedure Code, not for the one based on art. 25 para. 6 of the Criminal Procedure Code, because, in the latter case, the failure to resolve the civil action is seen as a sanction for a fault resulting from a procedural passivity.

By means of these provisions, the precautionary measures established within the criminal jurisdiction may be extended, even if the criminal proceedings have been concluded through a final decision, before the civil court. The continuation of criminal proceedings in civil proceedings thus protects the victims from the risk of resuming procedures already carried out or the insolvency of the debtors (former passive subjects of the civil action exercised during the criminal trial). Therefore, it remains for the victims to show the necessary diligence in acting before the civil court within 
the term provided by law. However, we consider that the term of 30 days could be extended (for example, to 60 days), as it is not sufficient enough to safeguard the interests of the victim and protect them from the sanction of termination stipulated in art. 397 para. 5 of the Criminal Procedure Code. The term thus proposed would appear to be a reasonable one, optimal for filing a new lawsuit, a thoroughly prepared one, possibly even taking into account some of the arguments of the final judgement of the criminal court, whose motivation is subject to a 30 days term (art. 406 of the Criminal Procedure Code, which this time is a recommended term, in the absence of express contrary stipulations).

\section{Conclusions}

As in the previous criminal procedure regulation, we notice that in the current regulation the solutions of the criminal court regarding the express way of solving the disjointed civil action remain uncovered. What is certain is that we are no longer speaking of the same judgement that solved the criminal action, but we are also in the presence of a decision taken by the criminal court, which separately solves the civil action disjointed from the criminal action, in a separate decision of the court, with its own remedies, distinct from those aimed by the criminal proceedings. Although regulation is intended to support the victim, this legislative gap can lead to law enforcement and interpretation issues. As a result, we believe that, either in art. 25 , or especially in art. 26, or even in art. 397, it would have been necessary to provide a paragraph that expressly enshrines the fact that "in case of disjunction of the civil action, the provisions of art. 25 and art. 397 shall apply accordingly, in so far as they are compatible". Therefore, de lege ferenda, we propose the insertion of some express provisions, regarding the resolution of the civil action in case of its disjunction.

\section{References}

Aspecte de practică neunitară în materia dreptului penal şi procesual penal. Minuta întâlnirii reprezentanților CSM cu preşedinții secțiilor penale de la ICCJ şi curțile de apel [Aspects of non-unitary practice in the field of criminal law and criminal procedure. Minutes of the meeting of the SCM representatives with the presidents of the criminal sections of the HCCJ and the courts of appeal]. (2014, December 12). https://www.juridice.ro/351877/aspecte-de-practica-neunitara-in-materiadreptului-penal-si-procesual-penal-minuta-intalnirii-reprezentantilor-csmcu-presedintii-sectiilor-penale-de-la-iccj-si-curtile-de-apel.html 
About an Ethical Interpretation of the Law. Resolution of the Civil Action ... Florin Octavian BARBU \& Claudiu Gabriel NEACŞU

Barbu, D. (2016). Drept procesual penal. Partea generală [Criminal procedural law. The general part]. Lumen.

Barbu, D. (2017). Controverse în jurisprudență cu privire la rezolvarea acțiunii civile în procesul penal [Controversies in jurisprudence regarding the settlement of civil action in criminal proceedings]. Comunicăre prezentată la sesiunea anuală de comunicări ştiințifice "10 ani de la aderarea României la Uniunea Europeană. Impactul asupra evoluției dreptului românesc”, Bucureşti, 31 martie 2017 [Lecture presented at the annual scientific communications session "10 years since Romania's accession to the European Union. The impact on the evolution of Romanian law", Bucharest, March 31, 2017]. "Academician Andrei Radulescu" Institute of Legal Research of the Romanian Academy.

Barbu, D. (2019). Controversies regarding the timing and manner of constituting a civil party in the criminal case. V alahia University Law Study, 34(2).

Constitutional Court of Romania. (2016). Decizie nr. 586 din 13 septembrie 2016 referitoare la excepția de neconstituționalitate a dispozițiilor art. 25 alin. (5) din Codul de procedură penală cu referire la dispozițiile art. 16 alin. (1) lit. f) din acelaşi act normativ [Decision no. 586 of September 13, 2016 regarding the exception of unconstitutionality of the provisions of art. 25 para. (5) of the Code of Criminal Procedure with reference to the provisions of art. 16 para. (1) lit. f) from the same normative act]. Monitorul Oficial al României, 1001, December 13, 2016.

High Court of Cassation and Justice. (2010). Decizia civilă nr. 1479 din 29 aprilie 2010 [Civil decision no. 1479 of April 29, 2010]. https://legeaz.net/spetedrept-comercial-iccj-2010/decizia-1479-2010

Judecătoria Cluj-Napoca. (2014a). Sentința penală nr. 326 din 28 martie 2014 [criminal sentence no. 326 of March 28, 2014]. http://portal.just.ro/211/SitePages/dosare.aspx

Judecătoria Cluj-Napoca. (2014b). Sentința penală nr. 505 din 07 mai 2014 [criminal sentence no. 505 of May 07, 2014]. http://portal.just.ro/211/SitePages/dosare.aspx

Neagu, I. (2020). Tratat de produră penală. Partea generală [A treatise on criminal procedure. The general part]. Universul Juridic.

Romanian Government. (2016). Ordonanță de urgență nr. 18 din 18 mai 2016 pentru modificarea şi completarea Legii nr. 286/2009 privind Codul penal, Legii nr. 135/2010 privind Codul de procedură penală, precum şi pentru completarea art. 31 alin. (1) din Legea nr. 304/2004 privind organizarea judiciară [Emergency Ordinance no. 18 of May 18, 2016 for the amendment and completion of Law no. 286/2009 regarding the Criminal Code, Law no. 135/2010 on the Criminal Procedure Code, as well as for 
completing art. 31 para. 1 of Law no. 304/2004 regarding the judicial organization]. Monitorul Oficial al României, 389, Mai 23, 2016.

Romanian Parliament. (1968). Codul de Procedură Penală [Criminal Procedure Code]. Buletinul Oficial, 145-146, November 12, 1968.

Romanian Parliament. (2009). Legea nr. 286/2009 privind Codul penal [Law no. 286/2009 regarding the Penal Code]. Monitorul Oficial al României, 510, July 24, 2009.

Romanian Parliament. (2010). Legea nr. 134/2010 privind Codul de procedură civilă [Law no. 134/2010 on the Civil Procedure Code]. Monitorul Oficial al României, 247, April 10, 2015 [republished].

Romanian Parliament. (2010). Legea nr. 135/2010 privind Codul de procedură penală [Law no. 135/2010 on the Criminal Procedure Code]. Monitorul Oficial al României, 486, July 15, 2010. 